MaPan : Jurnal Matematika dan Pembelajaran

p-ISSN: 2354-6883 ; e-ISSN: 2581-172X

Volume 9, No 1, June 2021 (119-135)

DOI: https://doi.org/10.24252/mapan.2021v9n1a8

\title{
THINKING STRUCTURE OF STUDENTS' UNDERSTANDING OF PROBABILITY CONCEPT IN TERM OF APOS THEORY
}

\author{
Syamsuri1), Cecep AHF Santosa2) \\ 1,2Department of Mathematics Education, Universitas Sultan Ageng Tirtayasa \\ 1,2J1. Raya Jakarta KM 4 Kota Serang Banten \\ Email: syamsuri@untirta.ac.id1), cecepanwar@untirta.ac.id²)
}

Received November 02, 2020; Revised December 05, 2020; Accepted May 25, 2021

\begin{abstract}
:
This study aims to analyze the mental structure experienced by students when understanding the concept of probability reviewed from APOS Theory and then suggests a lesson that accommodates the mental structure. APOS theory states that a learner forms a suitable mental structure when interpreting a mathematical concept. This study involved 106 third semester students who enrolled in Probability Theory. The students were given ACE (Activities, Classroom, Exercises) learning cycle treatment. After treatment, students were then given homework assignments that aim to reinforce the learning process. After the sixth week of learning, data were collected through a test. The results of this study are as follows: (a) the mental structure of students towards the concept of opportunity is still at the process level, not at the objectlevel, (b) Improving the learning of probability concept requires activities to improve verbal understanding, not only in the form of pictures and symbols. The alternative learning treatments are written in this article.
\end{abstract}

Keywords: Thinking Structure, Mental Structure, APOS Theory, Probability Concept, ACE Learning Cycle

\section{STRUKTUR BERPIKIR MAHASISWA TENTANG KONSEP PELUANG DITINJAU BERDASARKAN TEORI APOS}

\begin{abstract}
Abstrak:
Penelitian ini bertujuan untuk mendeskripsikan struktur mental yang dialami mahasiswa ketika memahami konsep peluang ditinjau dari teori APOS, yang menyarankan suatu pembelajaran yang sesuai dengan struktur mental mahasiswa. Teori APOS menyatakan bahwa seorang pembelajar membentuk suatu struktur mental yang sesuai ketika memaknai sebuah konsep matematis. Penelitian ini melibatkan 106 mahasiswa semester 3 yang mengambil mata kuliah Teori Peluang. Para mahasiswa tersebut diberikan perlakuan siklus pembelajaran ACE (Activities, Classroom, Exercises). Setelah pembelajaran di kelas selesai, para mahasiswa diberikan tugas sebagai pekerjaan rumah (homework) yang bertujuan sebagai penguatan terhadap apa yang telah dipelajari di kelas. Setelah pekan ke-enam pembelajaran, dilakukan pengambilan data berupa pengujian soal-soal yang setara dengan soal pada aktifitas di kelas maupun homework. Hasil penelitian ini sebagai berikut: (a) struktur mental mahasiswa terhadap konsep peluang masih berada pada tingkatan proses, belum pada tingkatan-
\end{abstract}


object, (b) Perbaikan perlakuan pembelajaran konsep peluang memerlukan adanya aktifitas dalam meningkatkan pemahaman secara verbal, tidak hanya dalam bentuk gambar dan simbol. Alternatif perlakuan pembelajarannya ditulis dalam artikel ini.

Kata Kunci: Struktur Berpikir, Struktur Mental, Teori APOS, Peluang, Siklus Pembelajaran ACE

How to Cite: Syamsuri \& Santosa, C. AHF. (2021). Thinking Structure of Students' Understanding of Probability Concept in Term of APOS Theory. MaPan : Jurnal Matematika dan Pembelajaran, 9(1), 119-135. https:/ / doi.org/10.24252/mapan.2021v9n1a8.

\section{INTRODUCTION}

$\Gamma$ hinking is very necessary for learning, especially learning mathematics, both at the school and college levels. According to Mason, Burton, and

L Stacey (2010), mathematical thinking relates to mathematical processes which include: specialization (trying special cases or special examples), generalizing (formulating relationship patterns), conjecturing (estimating the form of relationships and their results), and convincing (state the reasons why a statement is true). In addition, mathematical thinking is essential because one of the school mathematics standards in the learning process is that students are expected to develop mathematical reasoning (Kilpatrick, Swafford, \& Findell, 2001).

Several studies have attempted to reveal students' thinking in learning mathematics in higher education (Dreyfus, 2002; Tall, 2008; Arnon, Cottrill, Dubinsky, Oktac, Fuentes, Trigueros, \& Weller, 2013; Syamsuri, Purwanto, Subanji, \& Irawati, 2017; Syamsuri, 2016; Syamsuri \& Marethi, 2018). Tall (2008) argues that there is a transition process towards advanced mathematical thinking. The high-level mathematical thinking process can be in the form of representing, visualizing, generalizing, classifying, conjecturing, inducing, analyzing, synthesizing, abstracting, or formalizing (Dreyfus, 2002). Therefore, mathematical thinking at the college level is a higher-order thinking process. Therefore, learning mathematics in college involves a mental confusion as a connection between perception and action, then re-organization in a formal deduction, so as to be able to build new learning experiences through formal situations. 
One of the important ideas raised by Piaget regarding the mental development of human thinking is a reflective abstraction. In Arnon, Cottrill, Dubinsky, Oktac, Fuentes, Trigueros, and Weller (2013), Piaget argues that "The development of cognitive structures is due to reflective abstraction. . . " As for its relation to learning mathematics, Piaget suggested that reflective abstraction is a mental mechanism that is derived using logico-mathematical constructs. According to Piaget, there are at least two reflective abstraction characteristics, namely: (1) reflection, in the sense that awareness arises in thinking about the objects studied (content) and operations on these objects, and (2) reconstruction and re-organization of the objects occur. The objects and their operations at a higher level so that the results of these operations can be applied to objects for new operations. For example, initially, in constructing a function, the function is constructed as an operation on members of a set of domains to a set of ranges. Furthermore, at a higher level of thinking, functions can be operated in a function-space to proceed using new operations.

The application of the APOS theory in learning is based on the following assumptions (Dubinsky \& McDonald, 2001): (a) assumption on mathematical knowledge: a person's mathematical knowledge is his tendency to respond and solve mathematical problems and seek solutions to these problems by reflecting on the given problem, and then form the mental structure used in describing the problem, and (b) hypothesis on learning, namely: a person does not learn a mathematical concept directly. Instead, he will form a mental structure related to the concept. Learning will take place well if the learner's mind forms a mental structure in accordance with a given mathematical concept. If the expected mental structures are not formed, then learning about the concept will not work.

The two assumptions above indicate that the teaching objectives should contain strategies to help students form the expected mental structures and guide them in processing these mental structures to build an understanding of a mathematical concept. According to the APOS theory, the mental structure consists of action, process, object, and schema. The main mental mechanisms in forming these mental structures are interiorization and encapsulation (Dubinsky \& McDonald, 2001; Weller, Clark, \& Dubinsky, 2003).

APOS theory has been widely used in analyzing the formation of mathematical concepts at universities (Asiala, Brown, DeVries, Dubinsky, Mathews, \& Thomas, 1997; Weller, Arnon, \& Dubinsky, 2011; Maharaj, 2010; Syamsuri, Purwanto, Subanji, \& Irawati, 2017; Syamsuri \& Marethi, 2018) as well as in mathematics learning (Salgado \& Trigueros, 2015; Garcia-Martinez \& 
Parraguez, 2017). In concept construction, this theory describes the paths that students go through in constructing a mathematical concept. As for learning, this theory directs how to start and apply mathematics learning to make it easier for students to learn.

Regarding learning in accordance with the APOS theory, the ACE teaching cycle is a learning strategy suggested by Asiala, Brown, DeVries, Dubinsky, Mathews, and Thomas (1996). The ACE teaching cycle is a learning approach that is in accordance with the APOS theory consisting of three components: (A) activities, (C) classroom discussion, and (E) exercises that are carried outside classroom learning. In arranging activities, the APOS theory requires an assumption of a mathematical concept. The result of this analysis is called genetic decomposition. Genetic decomposition, a mathematical concept, is a mental sequence that is structured to build a mathematical concept that develops in a person's mind. Therefore, genetic decomposition requires a mental structure of action, process, object, and schema that describes certain mathematical concepts.

One of the important mathematical concepts is the concept of probability. According to their respective levels, the probability concept includes mathematical concepts taught at the elementary to college level. Most studies have investigated the difficulties and misconceptions in learning the concept of probability (Garfield \& Ahlgren, 1988; Diaz, 2007; Ang \& Shahrill, 2014). However, these studies have not investigated students' thought processes in understanding the concept of opportunity. By knowing the thought process, the lecturer can identify student mistakes in learning the concept of probability. Improvement and development of learning are to overcome the incomplete understanding of building mathematical concepts, provide effective guidance to students in learning to their ability level and guide students to integrate each knowledge they have learned. Therefore, it is necessary to study the mental structures that occur in students' minds when learning the concept of probability. And this article aims to describe the mental structure that occurs when understanding the concept of probability in terms of APOS theory.

In addition to suggestions related to the implementation of learning, these misconceptions need to be described through mental structures. Therefore, it is necessary to study the mental structures that occur in students' minds when learning the concept of probability. And this article aims to describe the mental structure that arises when understanding the concept of probability in terms of APOS theory. 


\section{METHODS}

This research is based on the APOS Theory (Dubinsky \& McDonald, 2001). Asiala, Brown, DeVries, Dubinsky, Mathews, and Thomas (1996) suggest a framework in research like this consists of theoretical analysis, teaching, and assessment of student learning. The existence of the APOS theory based on this framework is as shown in figure 1.

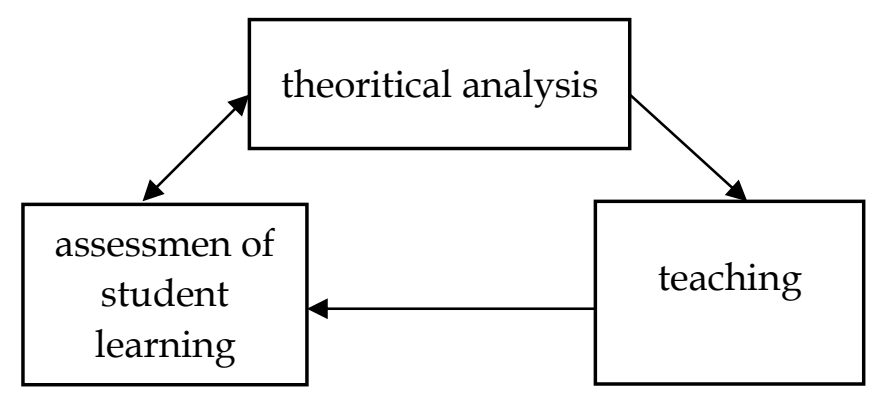

Figure 1. The Paradigm of this Study (Adopted from Asiala, Asiala, Brown, DeVries, Dubinsky, Mathews, and Thomas (1996))

In figure 1, the theoretical analysis is carried out by the researcher and is relative. It means that the researcher's sense subjectively predicts the mental structure needed when studying a mathematical concept. In addition, this theoretical analysis helps provide information related to the design of the learning implementation. Thus, learning-related data is obtained from the learning implementation. Furthermore, the data is analyzed to determine whether there is a need to modify the initial theoretical analysis of a mathematical concept.

\section{ACE Teaching and Data Collection Cycle}

This study involved 106 third-semester students who took the Probability Theory course at the Department of Mathematics Education, Sultan Ageng Tirtayasa University. The students were given ACE teaching cycle treatment during learning. The ACE teaching cycle starts with early learning activities designed to help develop the expected mental structure.

In classroom learning, researchers as teachers guide students to think and reflect on the activities given and their relationship with the concept of probability being learned. The lessons were carried out for six weeks, from August to October 2017. The materials presented were: sample space, events and operations, axioms of probability, combinatorics, conditional probability 
and independence, the law of probability doubling, the law of total probability, and the Bayes formula.

In classroom learning, researchers as teachers provide explanations related to the material and continue giving activities to give questions related to the material presented. Students can discuss the results of these activities with their friends or ask their teachers for explanations. After learning in class is completed, students are given homework assignments that aim to reinforce what has been discovered in class.

In the sixth week of learning, data collection was carried out in the form of testing on students. The instrument is in the form of questions that are equivalent to questions in-class activities or homework. The tasks are as follows:

1) Prove that $\mathrm{P}(\varnothing)=0$.

2) A teacher, when going to school, has two alternatives, namely: using public transportation or driving a private vehicle. He used to leave his place of residence at 6:17 a.m. Based on her experience, approximately $75 \%$ of them use public transportation to go to school, and $25 \%$ drive private vehicles. If you decide to use public transportation, there is a $60 \%$ chance that your child will arrive at 7:00 a.m. or less, whereas if he drives a private vehicle, the chances are $75 \%$ that he will arrive at 7:00 a.m. or less. If one day the teacher is in school at 07.00 . What are the chances of him using a private vehicle?

3) An allergist said that $50 \%$ of the patients he examined were allergic to dust. How many probabilities:

a. exactly three of the following patients were allergic to dust?

b. none of the next 4 patients was allergic to dust?

\section{RESULTS}

In describing the structure of student thinking when constructing a schema about the concept of probability, the researcher focuses on the probability axiom, conditional probability, and Bayes' Theorem. The data comes from the responses or answers to the questions given to the 106 students involved in this study.

\section{Thinking Structure Related to Axioms of Probability}

In Task 1 , formally proof of $\mathrm{P}(\varnothing)=0$ is as follows:

Suppose $A_{1}=\Omega$ and $A_{i}=\varnothing$, for $i \geq 2$. Then $A_{1}, A_{2}, \ldots$ are the sequence of independent events. Based on the axiom $(2) \mathrm{P}(\Omega)=1$ and axiom (3) then $P(\Omega)=$ 
$P\left(\cup_{i=1}^{\infty} A_{i}\right)=P(\Omega)+\sum_{i=2}^{\infty} P(\varnothing)$ which implies $\sum_{i=2}^{\infty} P(\varnothing)$ if $\mathrm{P}(\varnothing)$. This is only possible if $\mathrm{P}(\varnothing)=0$.

Task 1 is a question to determine the level of student thinking in using the axiom of probability. The axiom of probability consists of: (1) For each event A applies $0 \leq \mathrm{P}(\mathrm{A}) \leq 1,(2) \mathrm{P}(\Omega)=1$, and (3) if $\mathrm{A}_{1}, \mathrm{~A}_{2}, \ldots \in \mathrm{F}$ is a sequence of events that are mutually occurring independent, namely $A_{i} \cap A_{j}=\varnothing$, for each pair $i, j$ with $\mathrm{i} \neq \mathrm{j}$, then $P\left(\cup_{i=1}^{\infty} A_{i}\right)=\sum_{i=1}^{\infty} P\left(A_{i}\right)$ (Ghahramani, 2005). The integration of the three axioms will result in a statement that $\mathrm{P}(\varnothing)=0$. The following is the flow of student thinking that should be carried out when working on the problem.

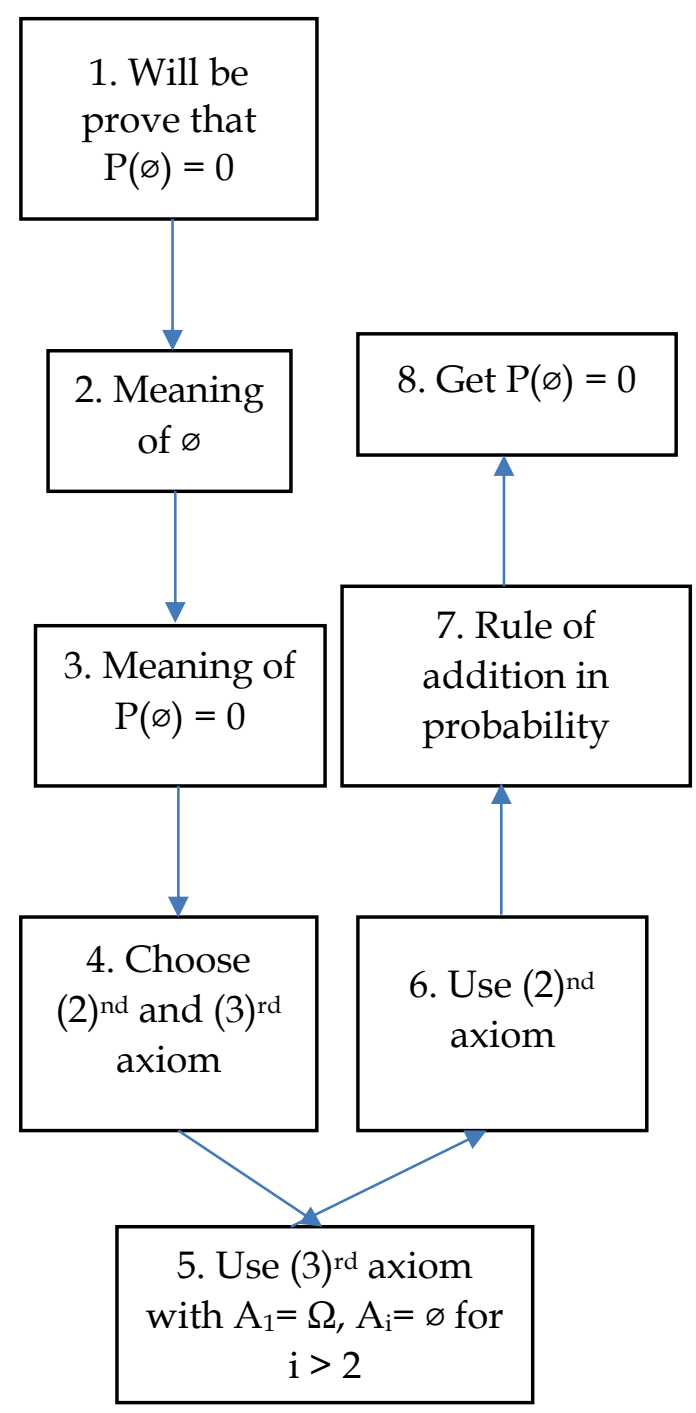

Figure 2. The Structure of Thinking to Solve $1^{\text {st }}$ Task 


\section{Empirically the following results were obtained}

Table 1. Student Thinking Levels for Task 1 Based on the APOS Theory

\begin{tabular}{|c|c|c|}
\hline Level & $\begin{array}{l}\text { Number of } \\
\text { Students } \\
\text { (Percentage) }\end{array}$ & Examples of Student Responses \\
\hline $\begin{array}{l}\text { Pre-action- } \\
\text { level }\left(1^{\text {st }}\right. \\
\text { and } 2^{\text {nd }} \\
\text { step) }\end{array}$ & $26(25 \%)$ & $\begin{array}{l}\text { Since the sample space } \varnothing \text { does not exist or has } \\
\text { no members, } \mathrm{P}(\varnothing)=0 \text {. } \\
\text { Meaning } \mathrm{P}(\varnothing)=0 \text { does not exist or is zero }\end{array}$ \\
\hline $\begin{array}{l}\text { Action- } \\
\text { level }\left(3^{\text {rd }}\right. \\
\text { step) }\end{array}$ & $42(40 \%)$ & $\begin{array}{l}\text { Give an example of a case. } \\
\text { Suppose that the probability of the empty set is } \\
\text { the occurrence of taking the yellow ball from } \\
\text { the box containing } 5 \text { blue balls and } 3 \text { red balls. }\end{array}$ \\
\hline $\begin{array}{l}\text { Process- } \\
\text { level }\left(4^{\text {th }},\right. \\
5^{\text {th }}, 6^{\text {th }}, \text { and }\end{array}$ & $26(25 \%)$ & $\begin{array}{l}\text { Using the axiom of probability but not yet } \\
\text { coherent. }\end{array}$ \\
\hline $7^{\text {th }}$ step) & & $\begin{array}{l}P(\varnothing)=0 \text { because every probability corresponds } \\
\text { to the first axiom that } 0 \leq P(A) \leq 1 \text {, so since } A \text { is } \\
\text { an empty set there are no members, then } \\
(\varnothing)=0 \text {. }\end{array}$ \\
\hline $\begin{array}{l}\text { Object- } \\
\text { level }\left(8^{\text {th }}\right. \\
\text { step) }\end{array}$ & $12(10 \%)$ & $\begin{array}{l}\text { Uses coherent axioms of probability. } \\
\text { Suppose } A_{1}=\Omega \text { and } A_{i}=\varnothing \text {, for } i \geq 2 \text {. Then } A_{1} \text {, } \\
A_{2}, \ldots \text { are the sequence of independent events. } \\
\text { Based on the axiom }(2) P(\Omega)=1 \text { and axiom }(3) \text {, } \\
\text { then } P(\Omega)=P\left(\cup_{i=1}^{\infty} A_{i}\right)=P(\Omega)+ \\
\sum_{i=2}^{\infty} P(\varnothing) \text {. which implies } \sum_{i=2}^{\infty} P(\varnothing) \text {. This is only } \\
\text { possible if } P(\varnothing)=0 \text {. }\end{array}$ \\
\hline
\end{tabular}

Based on table 1, the thinking structure of students is still dominant at the action or pre-action level, which is around $65 \%$. This result shows that most students still interpret the meaning of the symbol P $(\varnothing)=0$ and understand the statement by making appropriate case examples. The use of axioms in proving the statement $\mathrm{P}(\varnothing)=0$ has not yet appeared in the minds of many students. In addition, it indicates that the mental structures that are formed are mostly in action. The action that has been formed turns out to be imperfect into a process through the interiorization mechanism. Only about 35\% of students succeed in interiorizing this concept. Furthermore, from 35\% who succeeded during interiorization, only about $10 \%$ succeeded in completing it with an encapsulation mechanism to form the expected schema related to the axiom of probability. 


\section{Structure of Thinking Related to Bayes' Theorem}

Task 2: A teacher, when going to school, has two alternatives, namely: using public transportation or driving a private vehicle. He used to leave his place of residence at 6:17 a.m. Based on her experience, approximately $75 \%$ of them use public transportation to go to school, and $25 \%$ drive private vehicles. If you decide to use public transportation, there is a $60 \%$ chance that your child will arrive at 7:00 a.m. or less, whereas if he drives a private vehicle, the chances are $75 \%$ that he will arrive at 7:00 a.m. or less. If one day the teacher is in school at 07.00 . What are the chances of him using a private vehicle?

Task 2 is a question to determine the level of thinking of students in using various basic concepts of probability because Bayes' Theorem is a theorem in the theory of probability which has many relationships with various other basic concepts of probability, namely: conditional probability and independence, the law of multiplication of probability, and the law of total probability. In solving this word problem, of course, students must be able to interiorize or bring the task given to the mind. After that, it is hoped that students would adjust the problem given to the scheme that formed in their mind by encapsulation. The success of interiorization and encapsulation encourages the formation of a strong scheme related to Bayes's Theorem.

Bayes' Theorem reads as follows: Let $\left\{B_{1}, B_{2}, \ldots, B_{n}\right\}$ be an exclusive partition of the sample space $\Omega$ of an experiment. If $\mathrm{P}\left(\mathrm{B}_{\mathrm{i}}\right)>0$ for all $\mathrm{i}=1,2, \ldots$, $n$, then for any occurrence $\mathrm{A}$ of $\Omega$ with $\mathrm{P}(\mathrm{A})>0$ and for any $k, k=1,2, \ldots, n$, apply $\quad P\left(B_{k} \mid A\right)=\frac{P\left(A \mid B_{k}\right) P\left(B_{k}\right)}{\sum_{i=1}^{n} P\left(A \mid B_{i}\right) P\left(B_{i}\right)} \quad$ (Ghahramani, 2005). The integrated understanding of some of the basic concepts of probability will produce the correct response to task 2 . The following is the flow of student thinking that should be carried out when working on these questions.

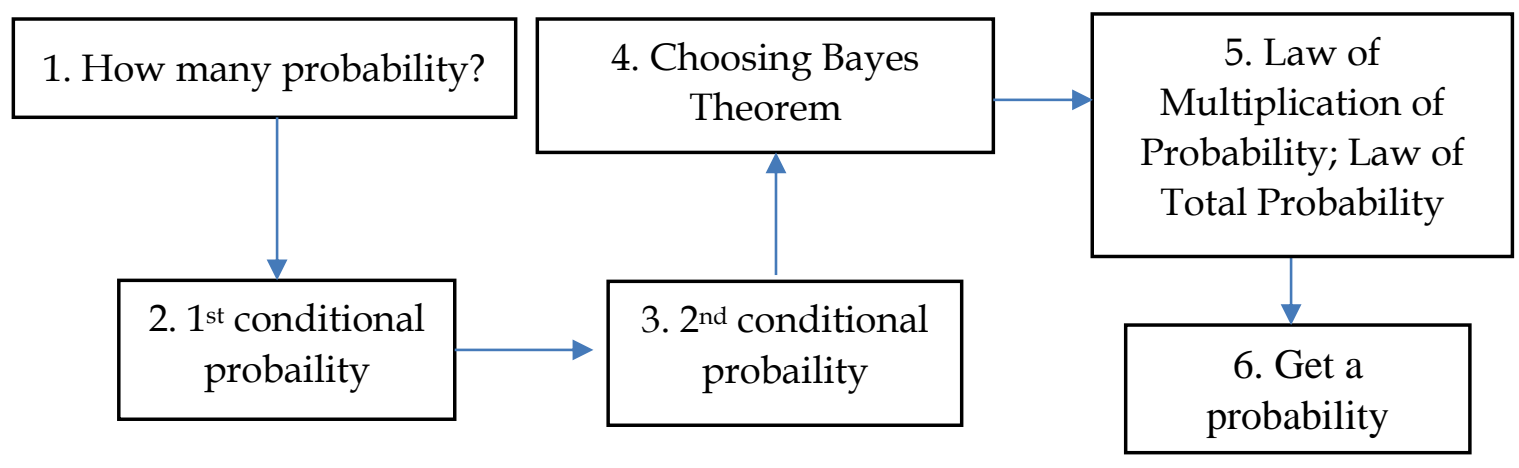

Figure 3. The Structure of Thinking to Solve the $2^{\text {nd }}$ Task 


\section{Empirically the following results were obtained}

Table 2. Student Thinking Levels for Task 2 Based on the APOS Theory

\begin{tabular}{|c|c|c|}
\hline Level & $\begin{array}{c}\text { Number of } \\
\text { Students } \\
\text { (Percentage) }\end{array}$ & Examples of Student Responses \\
\hline $\begin{array}{l}\text { Pre-action- } \\
\text { level (1 }{ }^{\text {st }} \\
\text { step) }\end{array}$ & $20(19 \%)$ & $\begin{array}{l}\text { Not knowing that this task uses conditional } \\
\text { probability. } \\
\mathrm{P}(\mathrm{A})=75 / 60 ; \mathrm{P}(\mathrm{B})=25 / 75 \\
\mathrm{P}(\mathrm{A} \cap \mathrm{B})=\mathrm{P}(\mathrm{A}) . \mathrm{P}(\mathrm{B})\end{array}$ \\
\hline $\begin{array}{l}\text { Action- } \\
\text { level }\left(2^{\text {nd }}\right. \\
\text { and } 3^{\text {rd }} \\
\text { step) }\end{array}$ & $49(46 \%)$ & $\begin{array}{l}\text { Uses conditional probability but experiences } \\
\text { errors. } \\
P(A)=0.75 ; P(B)=0.6 \\
P(C \mid A)=0.6 ; P(C \mid B)=0.75 \\
\text { Go back in search of } P(C \mid A)\end{array}$ \\
\hline $\begin{array}{l}\text { Process- } \\
\text { level } \\
\left(4^{\text {th }} \text { and } 5^{\text {th }}\right. \\
\text { step) }\end{array}$ & $19(18 \%)$ & $\begin{array}{l}\text { Using conditional probability, but haven't } \\
\text { thought about using Bayes' Theorem } \\
\mathrm{P}(\mathrm{A})=0.75 ; \mathrm{P}(\mathrm{B})=0.6 \\
\mathrm{P}(\mathrm{C} \mid \mathrm{A})=0.6 ; \mathrm{P}(\mathrm{C} \mid \mathrm{B})=0.75 \\
\mathrm{P}(\mathrm{C} \cap \mathrm{B})=\mathrm{P}(\mathrm{C} \mid \mathrm{B}) . \mathrm{P}(\mathrm{B})\end{array}$ \\
\hline $\begin{array}{l}\text { Object- } \\
\text { level }\left(6^{\text {th }}\right. \\
\text { step) }\end{array}$ & $18(17 \%)$ & $\begin{array}{l}\text { Using Bayes's Theorem, the Law of } \\
\text { Multiplication of Probability, and the Law of } \\
\text { Total Probability. } \\
\mathrm{P}(\mathrm{A})=0.75 ; \mathrm{P}(\mathrm{B})=0.6 ; \\
\mathrm{P}(\mathrm{C} \mid \mathrm{A})=0.6 ; \mathrm{P}(\mathrm{C} \mid \mathrm{B})=0.75 ; \\
\mathrm{P}(\mathrm{B} \mid \mathrm{C})=\mathrm{P}(\mathrm{B} \cap \mathrm{C}) / \mathrm{P}(\mathrm{B})= \\
\mathrm{P}(\mathrm{B} \cap \mathrm{C}) /[(\mathrm{P}(\mathrm{A}) \cdot \mathrm{P}(\mathrm{C} \mid \mathrm{A})+\mathrm{P}(\mathrm{B}) \cdot \mathrm{P}(\mathrm{C} \mid \mathrm{B})]\end{array}$ \\
\hline
\end{tabular}

Based on table 2, it is found that the thinking structure of students is still at the pre-action level, which is around 19\%. This result shows that students do not realize and understand that the tasks given are related to conditional probability. It may happen because students do Pseudo thinking. Pseudo thinking is caused by losing a stage of individual control, rote learning, and habitual factors (Nur, 2013). About 81\% have adjusted the schema on conditional probability with the given problem. In addition, it indicates that the mental structures that are formed are mostly in action. The action that has been formed turns out to be imperfect into a process through the interiorization mechanism. Only about 35\% of students succeed in interiorizing this concept. Furthermore, from 35\% who succeeded during interiorization, only about $18 \%$ 
succeeded in perfecting it with the encapsulation mechanism to form the expected schema related to Bayes' Theorem.

\section{Thinking Structure About Conditional Probability and Independence Event}

This $3^{\text {rd }}$ task is a question to determine the level of students' thinking in using various concepts of conditional probability and independent events because the concept of conditional probability and independent events is a basic theorem in probability theory.

The integrated understanding of some of the basic concepts of probability will produce the correct response to task 3 . The following is the flow of student thinking that should be carried out when working on these questions.

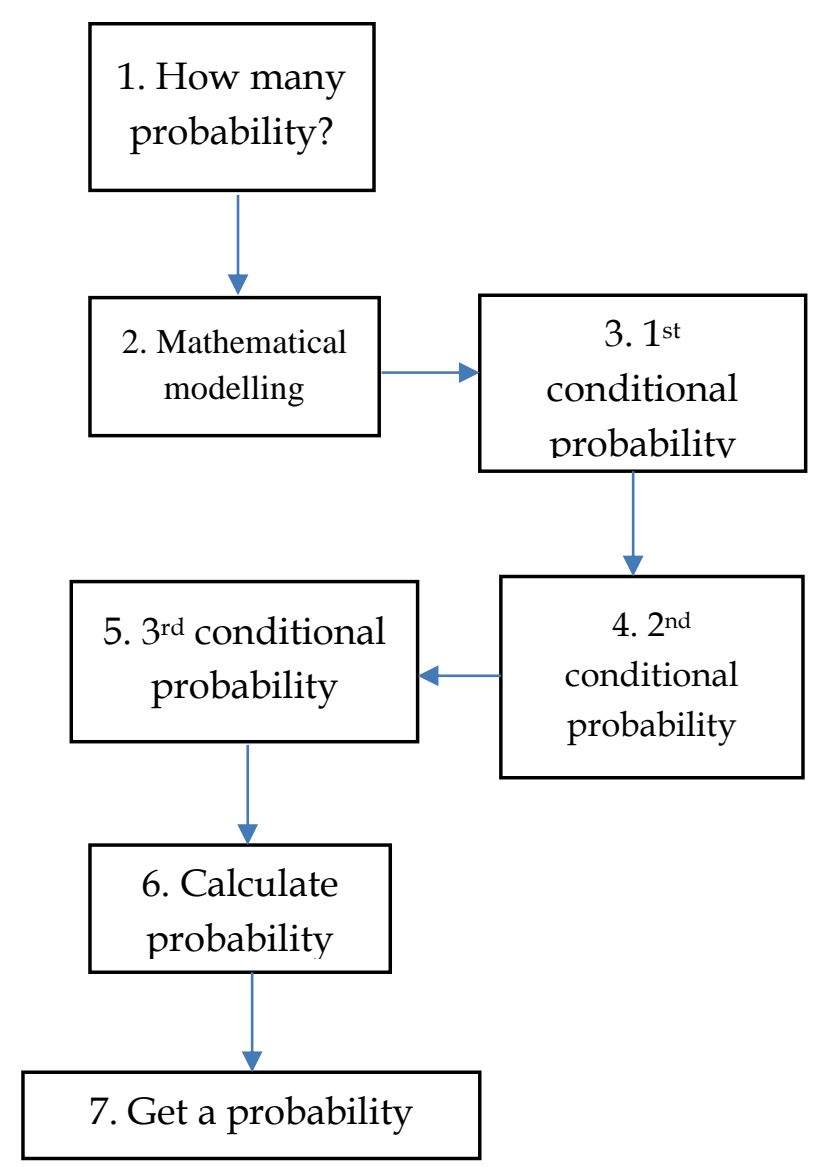

Figure 4. The Structure of Thinking to Solve the $3^{\text {rd }}$ Task 


\section{Empirically the following results were obtained.}

Table 3. Students' Thinking Levels for Task 3 Based on the APOS Theory

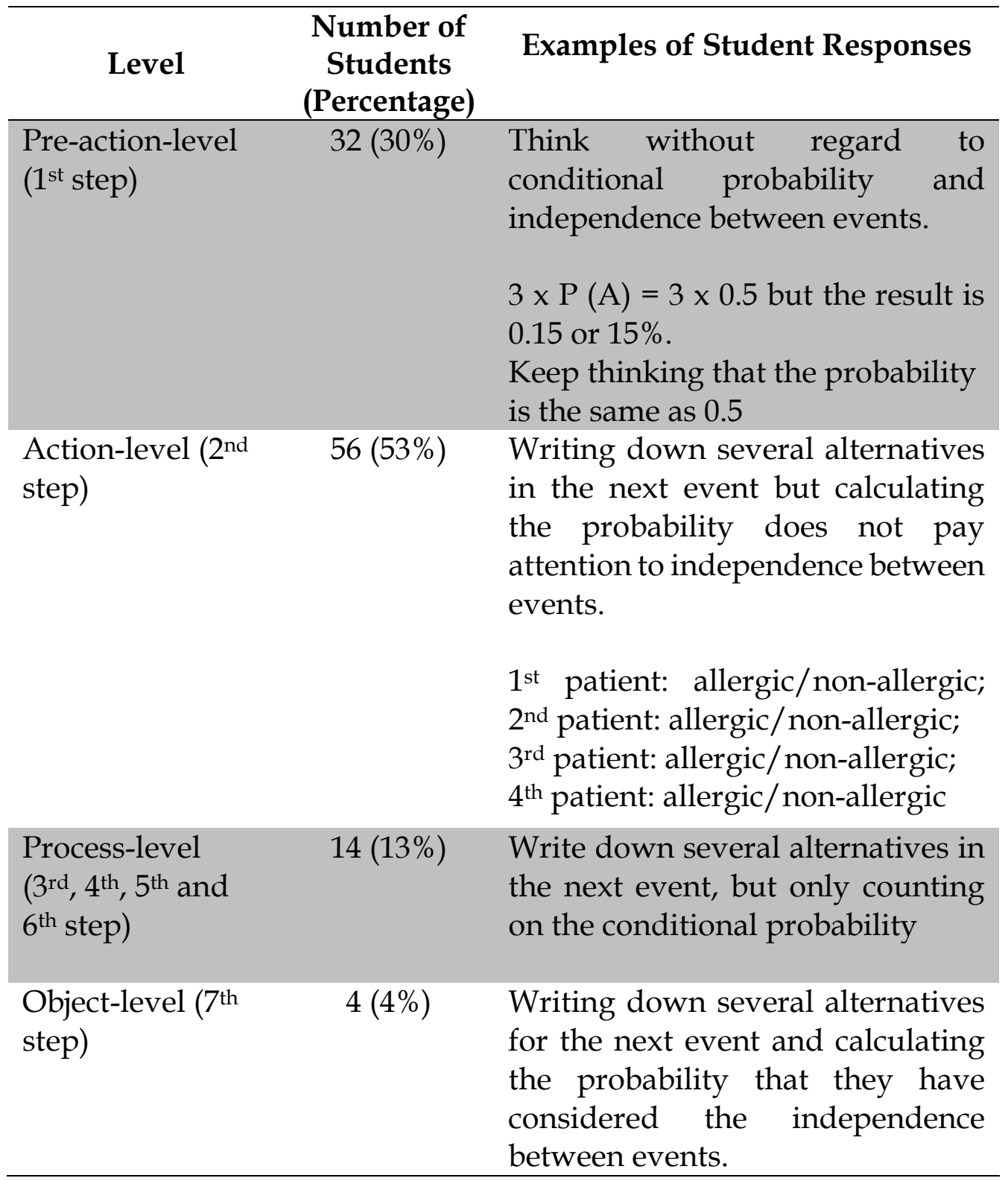

Based on table 3, it is found that the thinking structure of students is still at the pre-action and action levels, which is about $83 \%$. This result shows that students do not realize and understand that the tasks given are related to conditional probability. About $17 \%$ have adjusted the schema on conditional probability to the given problem. In addition, it indicates that the mental structures that are formed are mostly in action. The action that has been formed turns out to be imperfect into a process through the interiorization mechanism. 
Only about $17 \%$ of students succeed in interiorizing this concept. Furthermore, of the $17 \%$ who succeeded during the interiorization, only about $4 \%$ succeeded in perfecting it with an encapsulation mechanism so that the expected schema was formed regarding conditional probability and independence between events.

\section{DISCUSSION}

Based on the results, it is showing that most students have incomplete thinking structures. This result has happened because students reason inductively and have difficulty thinking deductively (Recio \& Godino, 2001). In addition, students have used wrong assumptions or claims, so they experience failure to encapsulate, de-encapsulate and generalize when understanding the concept of probability.

Based on Polya's opinion (in Meel, 2003), most students' understanding is at the inductive level because they can only provide examples of simple cases that fulfill proven statements. This matter reflects the lack of knowledge about applications, meanings, and logical relationships in understanding mathematical concepts (Lehman, 1977). Therefore, it is necessary to have a learning treatment that encourages mastering application, meaning, and developing logic.

Based on the results, it is necessary to improve learning, especially in particular learning that has been done. For question number 1 , the evaluation of proving statements involving the axiom of probability must emphasize the meaning of symbols. In the context of a complete mental structure of this probability axiom, the three axioms must be able to be encapsulated into object $P(\varnothing)=0$. If the student successfully carries out the encapsulation, then the student has a mental structure at the object level. With this mental structure, the framework for action, process, object, and schema in constructing other theorems derived from probability axioms will be easier. Therefore, learning in accordance with the formation of mental structures must consider the three axioms of probability.

To strengthen understanding of the three axioms of probability in forming mental structures, it is hoped that learning will use various representations related to the explanation of these axioms. These representations can be in the form of verbal, pictures, and symbols. The initial plan of learning that has been carried out is to use pictures and symbols. Therefore, this learning needs to be evaluated or added with activities using 
verbal representations or by expressing meaning in one's own sentences. This treatment is expected to encourage students to work using accurate definition and logic (Tall, 2010; Weber, 2003). As an alternative to learning the concept of probability, students have a mental structure at the object level, as follows:

Activity 1 (Symbols and Images)

(a) Suppose an attempt is made to toss five balanced coins.

(b) Suppose an experiment is made to take 3 balls from a box containing 5 red balls, 4 white balls, and 3 green balls.

(1) Illustrate experiment (a)

(2) Determine all the possible outcomes of the toss that will occur in (a) with the appropriate notation

(3) Determine the probability of each event in the experiment (a)

(4) Look for any events in experiment (a) where the probability are equal? Mention!

(5) Find the events that have zero chance on experiment (a)

(6) Illustrate experiment (b)

(7) Determine all possible draw results that will occur in (b) with the appropriate notation

(8) Determine the probability of each event in the experiment (b)

(9) Find out if there is an event in experiment (b) that has the same probability? Mention!

(10) Find the events that have zero chance on experiment (b)

Activity 2 (Verbal)

The Definition of Probability Axiom is given

A measure of probability $\mathrm{P}$ on $(\Omega, \mathrm{F})$ is a function $\mathrm{P}: \mathrm{F} \rightarrow[0,1]$ which satisfies the following conditions :

(i) For each event $\mathrm{A}$ applies $0 \leq \mathrm{P}(\mathrm{A}) \leq 1$.

(ii) $P(\Omega)=1$.

(iii) if $\mathrm{A}_{1}, \mathrm{~A}_{2}, \ldots \in \mathrm{F}$ is a sequence of events that are independent of each other, namely $\mathrm{Ai} \cap \mathrm{Aj}=\varnothing$, for each pair $\mathrm{i}$, $\mathrm{j}$ with $\mathrm{i} \neq \mathrm{j}$, then $P\left(\cup_{i=1}^{\infty} A_{i}\right)=\sum_{i=1}^{\infty} P\left(A_{i}\right)$

The pair $(\Omega, F, P)$ is called a probability space.

Explain in your own words the meaning of:

(1) the symbol P: F $\rightarrow[0,1]$,

(2) axiom (i), (3) axiom (ii), and (4) axiom (iii). 
For other questions, the interpretations in tables 2 and 3 can be used as a reference in formulating activities to help students build mental structures in accordance with the concepts they are learning.

\section{CONCLUSION}

The mental structure formed in a concept study is expected to be known in order to contribute to the determination of learning. In cognitive research like this, learning is defined as the mental adjustment structures formed in the learner's mind by a genetic decomposition of the probability concept. Based on the previous discussion, the results of this study are as follows: (1) the mental structure of students towards the concept of opportunity is still at the process level, not at the object-level, (2) Improving the treatment of opportunity concept learning requires activities to improve verbal understanding, not only in the form of pictures and symbols.

\section{REFERENCES}

Ang, L. H. \& Shahrill, M. (2014). Identifying students ' specific misconceptions in learning probability. International Journal of Probability and Statistics, 3(2), 23-29. https:// doi.org/10.5923/j.ijps.20140302.01.

Arnon, I., Cottrill, J., Dubinsky, E., Oktac, A., Fuentes, S. R., Trigueros, M., \& Weller, K. (2013). APOS Theory: A framework for research and curriculum development in mathematics education. Springer.

Asiala, M., Brown, A., DeVries, D., Dubinsky, E., Mathews, D., \& Thomas, K. (1996). A framework for research and curriculum development in undergraduate mathematics education. Research in Collegiate Mathematics Education, 2, 1-32. https:// doi.org/10.1090/cbmath/006/01.

Asiala, M., Cottrill, J., Dubinsky, E., \& Schwingendorf, K. E. (1997). The development of students' graphical understanding of the derivative. The Journal of Mathematical Behavior, 16(4), 399-431. https:/ / doi.org/10.1016/ S0732-3123(97)90015-8.

Diaz, C. (2007). Assessing students' difficulties with conditional probability and bayesian reasoning. International Electronic Journal of Mathematics Education, 2(3), 128-148. Retrieved from https://www.iejme.com/ article/assessing-students-difficulties-with-conditional-probability-andbayesian-reasoning.

Dreyfus, T. (2002). Advanced mathematical thinking processes. In D. O. Tall (Ed.), Advanced mathematical thinking (11th ed., pp. 25-41). Springer. https:/ / doi.org/10.1007/0-306-47203-1_2.

Dubinsky, E. D., \& McDonald, M. A. (2001). APOS : A constructivist theory of learning in undergraduate mathematics education research. in d. holton, 
M. Artigue, U. Kirchgraber, J. Hillel, M. Niss, \& A. Schoenfeld (Eds.), The teaching and learning of mathematics at university level (Vol. 7, pp. 275-282). Kluwer Academic Publishers. https://doi.org/10.1007/0-306-472317_25.

Garcia-Martinez, I., \& Parraguez, M. (2017). The basis step in the construction of the principle of mathematical induction based on APOS theory. Journal of Mathematical Behavior, 46(April), 128-143. https://doi.org/10.1016/j. jmathb.2017.04.001.

Garfield, J., \& Ahlgren, A. (1988). Difficulties in learning basic concepts in probability and statistics : implication for research. Journal for Research in Mathematics Education, 19(1), 44-63. https:/ / doi.org/10.2307/749110.

Ghahramani, S. 2005. Fundamental of prabobality and mathematical statistics. $2^{\text {nd }}$ Ed. Boston (USA): PWS Kent.

Kilpatrick, J., Swafford, J., \& Findell, B. (2001). Adding it up: helping children learn mathematics (N. R. C. mathematics learning study committee (ed.)). National Academies Press.

Lehman, H. (1977). On understanding mathematics. 27(2), 111-119.

Maharaj, A. (2010). An APOS analysis of students' understanding of the concept of a limit of a function. Pythagoras, 0(71), 41-52. https:/ / doi.org/10.4102/ pythagoras.v0i71.6.

Mason, J., Burton, L., \& Stacey, K. (2010). Thinking mathematically (2nd Edition). Pearson.

Meel, D. (2003). Models and theories of mathematical understanding: comparing pirie and kieren's model of growth of mathematical understanding and APOS theory. CBMS Issue in Mathematics Education American Mathematical Society, 12.

Nur, F. (2013). Faktor-faktor penyebab berpikir pseudo dalam menyelesaikan soal-soal kekontinuan fungsi linear yang melibatkan nilai mutlak berdasarkan gaya kognitif mahasiswa. MaPan: Jurnal Matematika Dan Pembelajaran, 1(1), 69-91. Retrieved from http:/ /journal.uin-alauddin.ac. id/index.php/Mapan/article/view/1127.

Recio, A. M., \& Godino, J. D. (2001). Institutional and personal meanings of mathematical proof. Educational Studies in Mathematics, 48, 83-99. https:/ / doi.org/10.1017/CBO9781107415324.004.

Salgado, H., \& Trigueros, M. (2015). Teaching eigenvalues and eigenvectors using models and APOS Theory. Journal of Mathematical Behavior, 39, 100120. https://doi.org/10.1016/j.jmathb.2015.06.005.

Syamsuri. (2016). Analysis of False-Semantic Proof Production in Undergraduate Mathematics Learning Based on APOS Theory. IOSR Journal of Research $\mathcal{E}$ Method in Education, 6(5), 44-49. https:// doi.org/ 10.9790/7388-0605054449. 
Syamsuri, Purwanto, Subanji, \& Irawati, S. (2017). Using APOS theory framework: why did students unable to construct a formal proof ? International Journal on Emerging Mathematics Education, 1(2), 135-146. http://dx.doi.org/10.12928/ijeme.v1i2.5659.

Syamsuri, S., \& Marethi, I. (2018). APOS analysis on cognitive process in mathematical proving activities. International Journal on Teaching and Learning Mathematics, 1(1), 1. https:// doi.org/10.18860/ijtlm.v1i1.5613.

Tall, D. (2010). Perception, operations and proof in undergraduate mathematics. Community for Undergraduate Mathematics Sciences Newsletter University of Auckland, 21-28.

Tall, D. (2008). The transition to formal thinking in mathematics. Mathematics Education Research Journal, 20(2), 5-24. https://doi.org/10.1007/ BF03217474.

Weber, K. (2003). A procedural route toward understanding the concept of proof. Proceedings of the 27th Conference of the International Group for the Psychology of Mathematics Education, 395-410.

Weller, K., Arnon, I., \& Dubinsky, E. (2011). Preservice teachers' understandings of the relation between a fraction or integer and its decimal expansion: Strength and stability of belief. Canadian Journal of Science, Mathematics and Technology Education, 11(2), 129-159. https://doi.org/10.1080/ 14926156.2011.570612.

Weller, K., Clark, J., \& Dubinsky, E. (2003). Student performance and attitudes in courses based on APOS theory and the ACE teaching cycle. Research in Collegiate Mathematics Education, 12, 97-131. http://dx.doi.org/10.1090/ cbmath/012/05. 